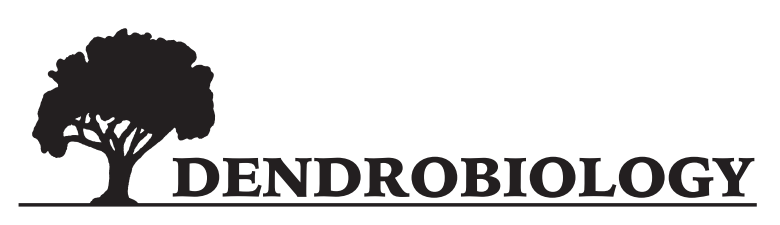

2017, vol. 78, 10-17

http://dx.doi.org/10.12657/denbio.078.002

Miguel Angelo Branco Camargo, Ricardo Antonio Marenco*

\title{
Tree growth over three years in response to monthly rainfall in central Amazonia
}

Received: 20 September 2016; Accepted: 24 March 2017

\begin{abstract}
In central Amazonia, annual rainfall distribution is characterized by a short mild dry season which is associated with a slight increase in irradiance and decline in relative humidity, but the effect of variations in these variables on tree growth is still unclear. The objective of this study was to determine how tree growth responds to monthly variations in some climate variables in central Amazonia. Trees of Protium hebetatum Daly (18-20 m tall) and Eschweilera collina Eyma (19-27 m tall) were used in the study and monthly growth rates were measured during 36 months (2010-2012). We also measured irradiance, temperature, rainfall, and relative humidity $(\mathrm{RH})$. Eschweilera and Protium grew at similar rates $(0.0557 \mathrm{~mm}$ month $\left.{ }^{-1}\right)$. Temperature and irradiance had no effect on tree growth of these species, but there was a trend for tree growth to increase with increasing both monthly rainfall and minimum relative humidity. If the dry season becomes longer and dryer in response to climate change one can expect that trees currently sensitive to mild drought stress will be the more affected.
\end{abstract}

Keywords: tropical forest, Protium, Eschweilera, soil water content.

Address: M. Camargo, R. Marenco, National Institute for Research in the Amazon - Av. André Araújo, 2936 -69067-375 - Manaus, AM - Brazil, e-mail: rmarenco@inpa.gov.br

\section{Introduction}

The Amazon forest is of paramount importance on a global scale because of the large amount of carbon stored in its vegetation, about 86 Pg (Saatchi et al., 2007). It has great biodiversity and plays a major role in the regional water cycle. Primary productivity of tropical forests may be limited by several factors, such as nutrient availability, irradiance, rainfall and soil water content (Brienen \& Zuidema, 2005; Wagner et al., 2012; Schippers et al., 2015; Stark et al., 2015).

Some studies have shown that in central Amazonia carbon gains tend to be higher in the rainy season (Malhi et al., 1998; Vieira et al., 2004; Wagner et al., 2014). However, there is not conclusive evidence that soil water content is a limiting factor in the dry season, as somehow gross primary production starts to increase at the end of the dry season (Restrepo-Coupe et al., 2013), when soil water content is still at its lower levels $(42 \% \mathrm{v} / \mathrm{v}$, Malhi et al., 1998). As photosynthesis rapidly responds to change in irradiance, it could be expected that cloudiness reduces carbon gain in the rainy season (Graham et al., 2003). Clouds reflect incoming solar radiation and absorb longwave radiation (i.e. alter the energy balance), and hence reduce the water pressure deficit and photosynthetically active radiation (PAR), which ultimately leads to reduced transpiration. In central 
Amazonia cloud cover can reduce solar radiation to about 15-17 MJ m${ }^{-2}$ day $^{-1}$ (Culf et al., 1998), and often some fog events can be observed, particularly in the rainy season (Anber et al., 2015). Although the solar radiation that reaches the forest is lower in the rainy season, there is no evidence that variation in PAR over the year affects gross primary productivity in the Amazon (Malhi et al., 1998; Wagner et al., 2012). In tropical rainforests, the effect of variation of temperatures on tree growth remains to be elucidated. In a tropical rainforest of Costa Rica, tree growth may negatively correlate with minimum temperatures, but in French Guiana, temperatures are weakly or no correlated with tree growth (Clark et al., 2003; Wagner et al., 2012). Understanding how tree species respond to variations in the physical environment is valuable information for modeling tree responses to climate changes. In this study, we hypothesize that tree growth is slower in the dry season and that tree growth is positively correlated with precipitation and minimum relative humidity, but negatively associated with temperature, and because reduced growth is expected in the dry season we also hypothesize that increased irradiance in the dry season does not lead to increase in tree growth. The objective of this study was to determine the effect of rainfall, air temperature, relative humidity, and irradiance on tree growth in a terra firme rainforest of the central Amazon.

\section{Materials and Methods}

\section{Study site and plant material}

The study was conducted at the Tropical Forest Experiment Station (ZF2 Reserve), located about 60 $\mathrm{km}$ north of Manaus $\left(02^{\circ} 36^{\prime} 21^{\prime \prime} \mathrm{S}, 60^{\circ} 08^{\prime} 11^{\prime \prime} \mathrm{W}\right)$. The study area is a plateau at a pristine terra firme rainforest in central Amazonia with an elevation of about 125 $\mathrm{m}$ above sea level. The annual rainfall is about 2,400 $\mathrm{mm}$, with a mild dry season ( $\leq 100 \mathrm{~mm}$ per month) which extends from June through September (Marenco et al., 2014; Dias \& Marenco, 2016), and annual potential evapotranspiration is about $1300 \mathrm{~mm}$. The rainy season begins in November and ends in May, October is a transition month. Mean temperature is about $26^{\circ} \mathrm{C}$. Because of cloudiness, maximum mean irradiance is about $1,000 \mu \mathrm{mol} \mathrm{m} \mathrm{m}^{-2} \mathrm{~s}^{-1}$ above the canopy, and relative humidity $(\mathrm{RH})$ varies from $70 \%$ at noon to $100 \%$ at night (Magalhães et al., 2014; Anber et al., 2015). The soil type is an Oxisol (Yellow Latosol) of clay texture (sand $11 \%$, silt $15 \%$ and clay $74 \%$ ), pH of 4.0 and low fertility (in $\mathrm{mg} \mathrm{kg}^{-1}$ ): Mehlich-P, 0.84; $\mathrm{K}$, 29; Ca, 13 and Mg, 14 (Magalhães et al., 2014).

Canopy trees at this area often reach $30 \mathrm{~m}$ tall, leaf area index ranges between 4.5 and 5.7, and above ground biomass is $300-350 \mathrm{t} \mathrm{ha}^{-1}$ (McWilliam et al., 1993; Malhi et al., 1998; Magalhães et al., 2014). In this region biodiversity of trees is very high, up to 280 species ha ${ }^{-1}$ (Oliveira \& Mori, 1999). Emergent canopy trees can reach $45 \mathrm{~m}$; mean tree density $(\geq 10 \mathrm{~cm}$ DBH - diameter at breast height) is 637 trees per ha (sample of $70 \mathrm{ha}$ ), the great majority $(85 \%)$ of trees has less than $30 \mathrm{~cm}$ in diameter; basal area is about 30 $\mathrm{m}^{2} \mathrm{ha}^{-1}$, and Lecythidaceae and Burseraceae are within the most abundant families (Rankin-de-Mérona et al., 1992). In the region some genera have high species diversity (e.g. Protium with 35 species and Eschweileira with 20 species); however, most of the tree species, such as Eschweilera collina Eyma (Lecythidaceae) and Protium hebetatum Daly (Burseraceae) are found at densities of less than one tree per hectare. Indeed, most tree species only occur rarely ( $\leq 1$ tree $\mathrm{ha}^{-1}$, Rankin-deMérona et al., 1992). Trees of Protium are often of medium stature ( $\leq 25 \mathrm{~m}$ tall) and particularly appreciated by a resinous exudate they produce. This resin is rich in aromatic substances. It is used for caulking boats, in varnish manufacture and as medicine (Rüdiger et al., 2007). In traditional medicine the resin is claimed to have healing, anti-inflammatory, and antiparasitic properties.

In this study we used two evergreen Amazonian species: Protium hebetatum and E. collina (hereinafter referred to as Protium and Eschweilera) and five trees per species. All the trees shared the same area, a terra firme plateau about $125 \mathrm{~m}$ asl, and their spatial ranged overlapped. These species were selected because their importance and the availability of trees in the study area. Eschweilera is used the timber industry, the trees can reach $30-35 \mathrm{~m}$ in height, and its wood density is $0.79 \mathrm{~g} \mathrm{~cm}^{-3}$ (Mori, 1989; Dias \& Marenco, 2016; Silva et al., 2015). Eschweilera trees used in the study had $20.2 \mathrm{~cm}$ in diameter (amplitude 12.5 to $30.2 \mathrm{~cm}$ ), height of $22.4 \mathrm{~m}(18.8-26.6 \mathrm{~m})$, and about 150 years of age (100-250, based on annual growth rates), while Protium trees had $13.7 \mathrm{~cm}$ in diameter $(10.7-15.6 \mathrm{~cm})$, a height of $19.4 \mathrm{~m}(17.7-20.5 \mathrm{~m})$, and estimated to be 200 years old (115-280 years). In both tree species, tree growth rates were measured at monthly intervals during 36 months (January 2010 to December 2012).

\section{Physical environment and tree growth}

Air temperature $\left(T_{\text {air }}\right)$, photosynthetically active radiation (PAR), relative humidity $(\mathrm{RH})$, and rainfall data were daily recorded in 2010-2012 above the forest canopy, at the top of a 40-m-tall observation tower $\left(02^{\circ} 35^{\prime} 21^{\prime \prime} \mathrm{S}, 06^{\circ} 06^{\prime} 55^{\prime \prime} \mathrm{W}\right)$. Irradiance was measured using a quantum sensor (Li-190SA, Li-Cor, NE, USA), and $T_{\text {air }}$ and RH were measured with a temperature-humidity sensor (Humitter 50y, Oy Vaisala, Finland). Both sensors were connected to a data logger (LI-1400, Li-Cor, Lincoln, NE, USA), which was 
set up to log data every 15 min for irradiance (data collected between $05 \mathrm{~h} 30$ and 18h30) and every 30 min for $T_{\text {air }}$ and RH (data collected day and night). PAR data were integrated over time to obtain daily PAR values $\left(\mathrm{mol} \mathrm{m}^{-2} \mathrm{day}^{-1}\right)$. Rainfall data were recorded using a rain gauge (Em5b, Decagon, WA, USA). Tree diameter at breast height (DBH, i.e. $1.3 \mathrm{~m}$ above the ground) was measured at monthly intervals during 36 months (2010-2012) by using stainless steel dendrometric bands installed three years before the beginning of the experiment. The increment in tree girth was measured using digital calipers $(0.01 \mathrm{~mm}$ accuracy, Mitutoyo Sul Amaricana, Sao Paulo, Brazil). In addition, in 2011 and 2012 we also measured soil water content (after drying the soil samples at $105^{\circ} \mathrm{C}$ ) of undisturbed soil samples collected (100 to $200 \mathrm{~mm}$ depth) in the wet and dry season (26 samples per season), as previously described (Marenco et al., 2014).

\section{Statistical analyses}

To assess differences between species and monthly growth rates, and the interaction between these variables, we conducted a repeated-measures analysis of variance using the following hierarchical model:

$$
\begin{gathered}
\mathrm{Y}_{\mathrm{ijk}}=\mu+\alpha_{\mathrm{i}}+\beta_{\mathrm{j}}+\gamma_{\mathrm{k}}+(\alpha \beta)_{\mathrm{ij}} \\
(\alpha \beta \gamma)_{\mathrm{ijk}}+\varepsilon_{\mathrm{ijk}}
\end{gathered}
$$

where $\mu$ is a constant, $\alpha_{i}, \beta_{\mathrm{i}}$, and $\gamma \mathrm{k}$ represent the effect of $\mathrm{i}$-th species, $\mathrm{j}$-th years, and k-th months, $(\alpha \beta)_{\mathrm{ij},},(\alpha \gamma)_{\mathrm{ik},}(\beta \gamma)_{\mathrm{j},}$, and $(\alpha \beta \gamma)_{\mathrm{ijk}}$ denote the effect of the interactions, and $\varepsilon_{\mathrm{ijk}}$ indicates the error term. To describe the association between climate variables (temperature, relative humidity, irradiance and rainfall) principal component analysis was used, and in this analysis, the growth rates of both species were used as supplementary variables. The climate variable more closely associated with tree growth rates were plotted against tree growth to observe the trends. Statistical analyses were carried out using $\mathrm{R}$ statistical packages (R Development Core Team).

\section{Results}

During the study period mean temperature was $25.7^{\circ} \mathrm{C}$, mean minimum and maximum temperatures $\left(T_{\min }, T_{\max }\right)$ were 22.2 and $30.5^{\circ} \mathrm{C}$, respectively (Fig. 1). The mean relative humidity was $85.8 \%$, and ranged from $50 \%$ at midday to $98 \%$ at night. Daily

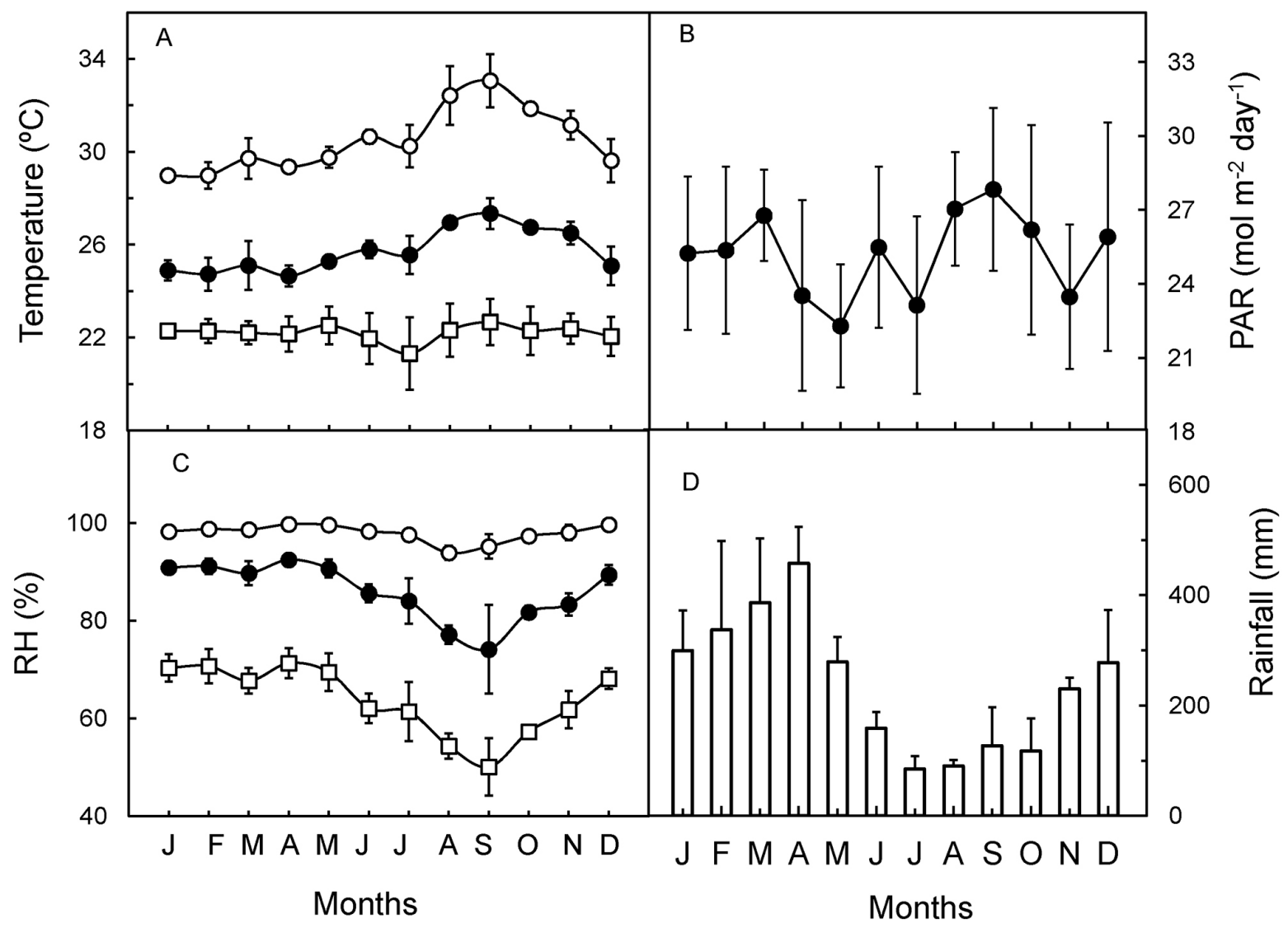

Fig. 1. Monthly variation of air temperature (A), photosynthetically active radiation (PAR, B), relative humidity (RH, C), and rainfall (D) recorded at the top of a $40 \mathrm{~m}$ tall tower at the ZF2-Reserve in central Amazonia. The open circle, solid circle and the square represent maximum, mean and minimum values of temperature (A) and RH (C). Each symbol represents the mean $( \pm$ SD ) recorded for the same month between 2010 and 2012 


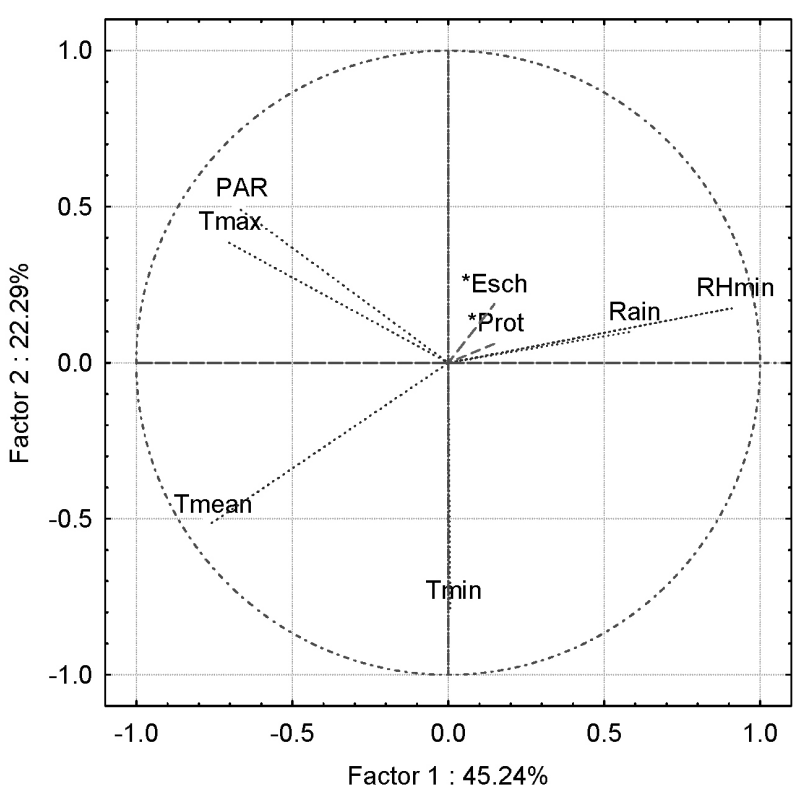

Fig. 2. Principal component analysis of the climate variables, with monthly tree growth of Eschweilera (Esch) and Protium (Prot) as supplementary variables

PAR ranged from 22.3 to $27.8 \mathrm{~mol} \mathrm{~m}^{-2}$ day $^{-1}$, with a mean of $25.2 \mathrm{~mol} \mathrm{~m}^{-2}$ day $^{-1}$. Mean annual rainfall was $2,845 \mathrm{~mm}$ and mean monthly rainfall ranged from $84.8 \mathrm{~mm}$ in July to $457.5 \mathrm{~mm}$ in April (Fig. 1). Soil water content (SWC) was lower in the dry season $(0.40 \mathrm{v} / \mathrm{v})$ than in the rainy season $(0.46 \mathrm{v} / \mathrm{v}, p=$ $0.012)$. The association between tree growth and soil water content (2011-2012) was not significant ( $p>$ 0.05 , data not shown). As maximum RH was always quite close to $100 \%$ (at night) we only used the minimum RH (recorded at midday) to assess its effect on tree growth, as it is the minimum rather than the maximum RH that can eventually limit photosynthesis. As RH was usually high at night, occasionally some fog events (often dissipating by 07:30 h) were observed early in the morning. The axis 1 and 2 (factors 1,2) explained 45.2 and $22.9 \%$ of the total

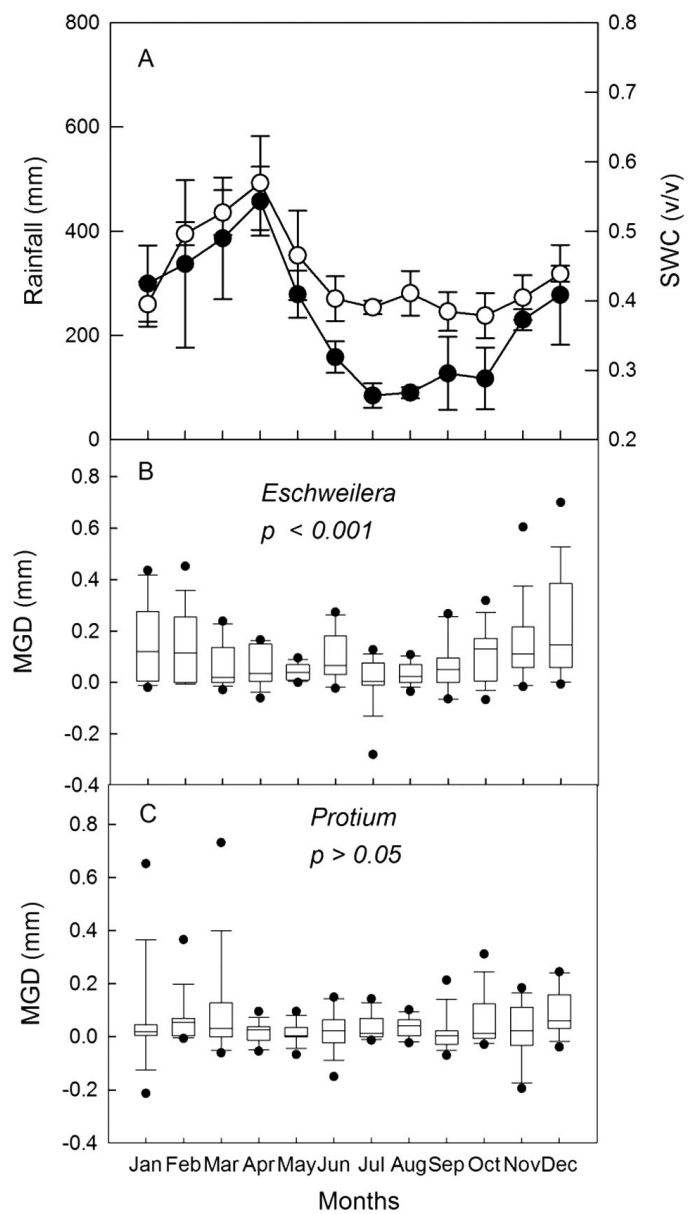

Fig. 3. Rainfall (filled circle) and soil water content (SWC, open circle) over time (A) and mean monthly growth in diameter (MGD) in Eschweilera (B) and Protium (C) in a terra firme rainforest at the ZF2-Reserve in central Amazonia. The SWC (panel A) is for the year 2011 and 2012, whereas rainfall data correspond to the mean ( \pm SD) of three years (2010-2012). In panels B-C, each value represents the mean of five trees repeatedly measured for 36 months, and in these panels, the boundaries of the box indicate the 25th and 75 th percentile, the solid line within the box shows the median, the outliers are indicated by dots

Table 1. Repeated measures analysis of variance of the effect of year, month and species on monthly tree growth in diameter. The same tree [five replications $(r)$ per species] was repeatedly measured for three years (2010-2012) at 1-month intervals (January to December). Bold numerals indicate significance

\begin{tabular}{lrcccc}
\hline \multicolumn{1}{c}{ Source of Variation } & d.f. & Sum of squares & Mean square & $F$ value & $P$ value \\
\hline Species (S) & 1 & 0.218285 & 0.218285 & 3.46933 & 0.099530 \\
Error [S (R-1)] & 8 & 0.503347 & 0.062918 & & 0.30748 \\
Year (Y) & 2 & 0.011495 & 0.005748 & 0.739549 \\
Year*Species & 2 & 0.015741 & 0.007870 & 0.42104 & 0.663425 \\
Error [S(R-1) [Y-1)] & 16 & 0.299084 & 0.018693 & & \\
Month & 11 & 0.481696 & 0.043791 & 5.07001 & 0.000004 \\
Month*Species & 11 & 0.228214 & 0.020747 & 2.40203 & 0.011731 \\
Error [S (R-1) [M-1)] & 88 & 0.760071 & 0.008637 & & \\
Year*Month & 22 & 0.294928 & 0.013406 & 1.14797 & 0.301332 \\
Year*Month*Species & 22 & 0.110776 & 0.005035 & 0.43118 & 0.988384 \\
Error [S(R-1) [Y-1) [M-1)]] & 176 & 2.055307 & 0.011678 & & \\
\hline Total & 359 & & & &
\end{tabular}




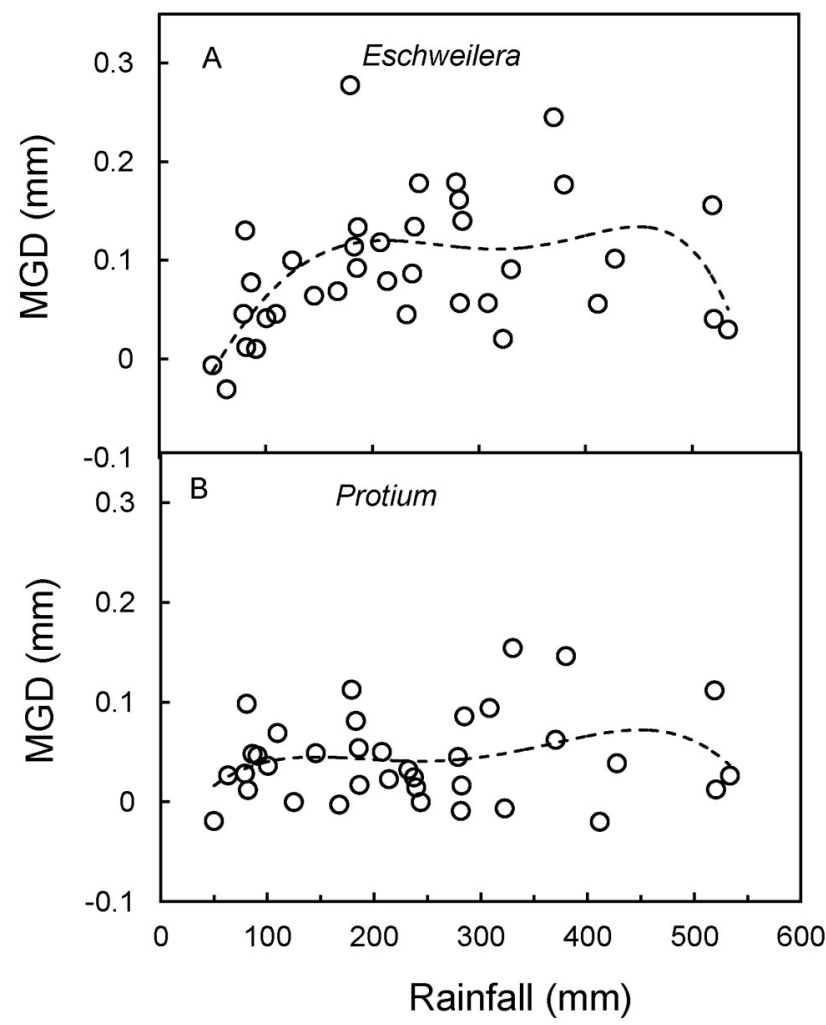

Fig. 4. Monthly growth in diameter (MGD) plotted against monthly rainfall intensity in Eschweilera collina (A) and Protium hebetatum (B). The dashed line shows a smoothed trend drawn through the points

variance (Fig. 2). One can see in this figure that tree growth rates of both species were more related with rainfall intensity and minimum relative humidity. In Fig. 2, it also showed that there was no association between tree growth and maximum temperature or

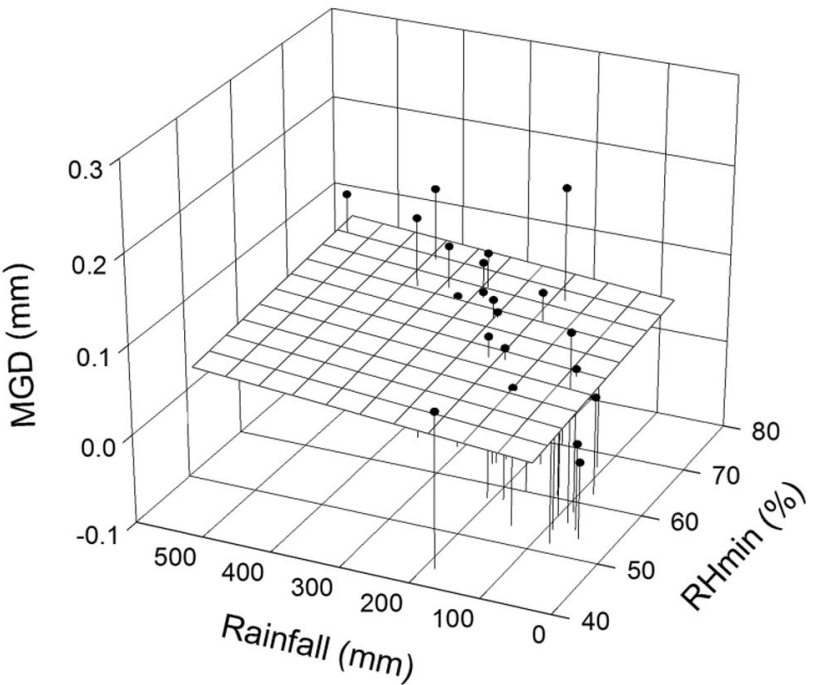

Fig. 5. Monthly growth in diameter (MGD) across species plotted against monthly rainfall and minimum relative humidity (RHmin). One can see that MGD tends to increase with rainfall and RHmin, the two variables more closely associated with tree growth in the Principal components analysis
PAR. Also, there was no relationship between tree growth and mean temperature $(p>0.05$, data not shown).

There was no significant difference between species or years on monthly growth rates (Table 1), and across species a mean value of $0.0557 \mathrm{~mm}$ month $^{-1}$ was found (Fig. 3). The interaction between species and months was significant $(p=0.011)$. Thus, the growth rate trend is shown separately for each species. Eschweilera tended to grow faster during the wettest months of the year, particularly in November, December, January and February (Fig. 3A). The growth of Eschweilera steadily increased up to about $250 \mathrm{~mm}$ per month; thereafter, it tended to remain stable up to about $400 \mathrm{~mm}$ and then it tended to decline (Fig. 4A). Protium, on the other hand, grew at almost the same rate over time (Fig. 4B). As the PCA analysis suggested some association between rainfall and minimum relative humidity (RHmin) and monthly growth in diameter (MGD), a two-dimensional plot was constructed to shown a general trend of the tree growth of both species combined versus RHmin and rainfall. In Fig. 6 one can see that tree growth tends to increase with increasing both rainfall and minimum relative humidity.

\section{Discussion}

Climate conditions recorded in this study are similar to that previously recorded in the same area (Dias \& Marenco, 2016; Marenco et al., 2014). Our PAR values, however, are lower than those reported by Malhi et al. (1998), but in that year (1995/1996) annual rainfall intensity was lower $(2130 \mathrm{~mm})$ that the rainfall values we measured.

In tropical forests, high rainfall intensity in the rainy season is often associated with reduction in the levels of irradiance in response to cloudiness (Mulkey et al., 1996; Wagner et al., 2014). Therefore, it can be expected that an increase in irradiance leads to increase in tree growth (Graham et al., 2003; Stark et al., 2015). Thus, absence of an effect of irradiance on tree growth seems to be contrary to expectations as it has been found that supplemental artificial light applied to forest canopy to compensate reduction in irradiance caused by cloud cover can improve carbon gain (Graham et al., 2003). However, if we take into account that in the central Amazon some clouds still cover the sky in the short dry season, thereby avoiding high variation over the year (in the study period: 24.8 -rainy season-versus $25.9 \mathrm{~mol} \mathrm{~m}^{-2}$ day $^{-1}$ in the dry season), we can reach to the conclusion that changes in irradiance intensity across rainfall seasons are not too large to affect tree growth. Indeed, our results agree with those reported by Malhi et al. (1998) who find no significant effect of variation in 
irradiance over time on carbon gain in central Amazonia. Nevertheless, our findings do not support the hypothesis that irradiance is not a limiting factor of tree growth in the rainy season in central Amazonia. This is because in this region variations in daily mean irradiance are not too large across rainfall seasons. For example, between September 1995 and August 1996, Malhi et al. (1998), found a mean value of about $16 \mathrm{MJ} \mathrm{m}^{-2} \mathrm{day}^{-1}$ (or $33.2 \mathrm{~mol} \mathrm{~m}^{-2}$ day $^{-1}$, assuming a conversion factor to PAR of 0.45/0.217) with little variation over the year. For comparison, Mulkey et al. (1996) reported $14-15 \mathrm{MJ} \mathrm{m}^{-2}$ day $^{-1}$ in the rainy season against $20-23 \mathrm{MJ} \mathrm{m}^{-2}$ day $^{-1}$ in the dry season of a tropical dry forest.

Relative humidity was particularly high at night, which significantly reduces VPD and thereby leaf transpiration. It is well-known that the living tissues of leaves do not absorb water vapor from the atmosphere. Indeed, leaves can even lose water to quite humid air (Bennett, 1879). Although the dead leaf tissue of Tillandsia usneoides (a rootless epiphyte) can absorb water vapor from the atmosphere, such tissue hydration has no effect of leaf physiology (Martin et al., 2013). On the other hand, condensed water droplets (fog) can substantially contribute to the water balance of plants in those regions where long-duration fog events often occur (Burgess \& Dawson, 2004). Nevertheless, because of their short duration, the contribution of these transient radiation-fog events to the water balance of the forest ecosystem in central Amazonia seems to be negligible (Bastable et al., 1993). The values of SWC we recorded $(0.40$ to $0.46 \mathrm{v} / \mathrm{v}$ ) are quite close to the values of $0.42 \mathrm{v} / \mathrm{v}$ (in the dry season) and $0.47 \mathrm{v} / \mathrm{v}$ (rainy season) reported by Malhi et al. (1998). In the Yellow Latosols (ferrasol the international soil classification system) of this region, the permanent wilting point - PWP (water content at a tension of $1500 \mathrm{kPa}$ ) is often found at SWC of $0.30 \mathrm{v} / \mathrm{v}$ (Ranzani, 1980; Marques et al., 2004), which is lower that the SWC we recorded in the dry season $(p<0.001)$. Even in soil with high SWC, stomatal closure can occur, particularly at midday, when the loss of water by transpiration exceeds the capacity of xylem to transport water from the roots to the leaves. This could explain the trend to reduced growth rates observed in Eschweilera in the dry season. The tallest trees were observed in this species, which can be one of the reason for the variation of tree growth over time we found in this species (Fig. 4), as transpiration is higher in tallest trees - they are more exposed to windy conditions.

We failed to detect any effect of temperatures on tree growth. Absence of response to temperature indicates that daily temperatures are within the optimal range for photosynthesis. Perhaps for this reason, some results have shown opposite directions. Clark et al. (2003), for example, reported that trees of some species can grow slowly as the minimum temperature increases. Wagner et al. (2012), on the other hand, found that minimal temperature is slightly positively correlated with tree growth in French Guiana. They also reported no effect of maximum temperature on tree growth.

In both species we recorded negative changes in diameter (decrements), which is not unexpected in measurements made at monthly interval throughout the year. This often occurs at midday or in the dry season due to pole contraction in response to water loss by transpiration (Zweifel et al., 2000). Under severe dryness, the trunk of Adansonia sp. can contract up to $3 \mathrm{~cm}$ by the end of the dry season (Chapotin et al., 2006). Stem shrinking has been reported previously in the Amazon region (Gourlet-Fleury \& Houllier, 2000; Vieira et al., 2004).

In this study we found that Eschweilera tended to grow a little faster than Protium, but the high variation in growth rate along the year makes it difficult to detect significant difference between species ( $p$ $=0.099$ ). This is because trees do not often grow at constant rates over time (Breitsprecher \& Bethel, 1990; Clark \& Clark, 1994; Baker et al., 2003). Although a sampling time of 36 months provided quite useful information, more robust data could be obtained increasing the sampling size (number of trees or number of species) or increasing the sampling time (i.e. a period longer than three years). A limitation of small sample size (10 trees) is the difficulty of exploring all the random variations in soil and topography conditions of a given area. To reduce the effect of random variation in soil characteristics, the study area was circumscribed to a plateau (120-130 masl) with rather similar soil conditions.

In several studies it has been reported a positive correlation between rainfall and tree growth in the Amazon region (Dünisch et al., 2003; Vieira et al., 2004; Wagner et al., 2012). However, some species are rather unresponsive to variation in rainfall over time (e.g. Parkia pendula, Grogan \& Schulze, 2012). Evergreen trees, for example, can only show a short interruption in growth rates at the end of the dry season (Worbes, 1999). In other tropical rainforests, there is only a positive correlation between tree growth and rainfall in some months of the year (Brienen \& Zuidema, 2005). Tree growth can also vary from year to year and in some species annual rainfall may show no correlation with the annual growth patterns of trees (Clark \& Clark, 1994). In an evergreen rainforest of India, it seems to be a lag between the peak in rainfall and the maximum tree growth rates (Pelissier \& Pascal, 2000). Most models predict that the dry season will extend in large areas (eastern-central) of the Amazon (Duffy et al., 2015). If these models are correct, it seems plausible to assume that some species will be more affected 
than others by more prolonged dry periods. Variations in growth rates among species can be related to the ability of trees to develop tap roots large enough to explore the deepest layer of the soil during the dry season. Tree species adapted to low water availability allocate more carbon to the root system, so that they are able to explore the deepest layer of the soil (Canadell et al., 1996).

Although temperature and irradiance are critical factors in plant functioning, variations in temperature and irradiance did not influence the monthly growth in diameter of the studied species, suggesting that over the year such variations are not large enough to affect their growth rates. If the dry season becomes longer (as predicted by climate models), it seems plausible to conclude that trees that are rather sensitive to mild dry seasons are more likely to be more affected by a prolonged dry season.

\section{Acknowledgments}

To the Foundation for Research Support of the State of Amazonas (FAPEAM), CNPq (302041/20150) and the Ministry of Science, Technology, Innovation and Communication - National Institute for Research in the Amazon (MCTIC-INPA). We also thank the valuable comments and suggestions of the anonymous reviewers that greatly contributed to improve the manuscript.

\section{References}

Anber U, Gentine P, Wang S \& Sobel AH (2015) Fog and rain in the Amazon. Proceedings of the National Academy of Sciences 112: 11473-11477.

Baker TR, Burslem, DFRP \& Swaine MD (2003) Associations between tree growth, soil fertility and water availability at local and regional scales in Ghanaian tropical rain forest. Journal of Tropical Ecology 19: 109-125.

Bastable HG, Shuttleworth WJ, Dallarosa RLG, Fisch G \& Nobre CA (1993) Observations of climate, albedo, and surface radiation over cleared and undisturbed Amazonian forest. International Journal of Climatology 13: 783-796.

Bennett AW (1879) Absorption of water by the leaves of plants. The American Naturalist 13: 20-24.

Breitsprecher A \& Bethel JS (1990) Stem-growth periodicity of trees in a tropical wet forest of Costa Rica. Ecology 71: 1156-1164.

Brienen RJW \& Zuidema PA (2005) Relating tree growth to rainfall in Bolivian rain forests: a test for six species using tree ring analysis. Oecologia 146: $1-12$.

Burgess SSO \& Dawson TE (2004) The contribution of fog to the water relations of Sequoia sem- pervirens (D. Don): foliar uptake and prevention of dehydration. Plant, Cell \& Environment 27: 1023-1034.

Canadell J, Jackson RB, Ehleringer JB, Mooney HA, Sala OE \& Schulze ED (1996) Maximum rooting depth of vegetation types at the global scale. Oecologia 108: 583-595.

Chapotin SM, Razanameharizaka JH \& Holbrook NM (2006) Baobab trees (Adansonia) in Madagascar use stored water to flush new leaves but not to support stomatal opening before the rainy season. New Phytologist 169: 549-559.

Clark DA \& Clark DB (1994) Climate-induced annual variation in canopy tree growth in a Costa Rican tropical rain forest. Journal of Ecology 82: 865-872.

Clark DA, Piper SC, Keeling CD \& Clark DB (2003) Tropical rain forest tree growth and atmospheric carbon dynamics linked to interannual temperature variation during 1984-2000. Proceedings of the National Academy of Sciences 100: 58525857.

Culf AD, Fisch G, Lean J \& Polcher J (1998) A comparison of Amazonian climate data with general circulation model simulations. Journal of Climate 11: 2764-2773.

Dias DP \& Marenco RA (2016) Tree growth, wood and bark water content of 28 Amazonian tree species in response to variations in rainfall and wood density. iForest-Biogeosciences and Forestry 9: 445-451.

Duffy PB, Brando P, Asner GP \& Field CB (2015) Projections of future meteorological drought and wet periods in the Amazon. Proceedings of the National Academy of Sciences 112: 13172-13177.

Dünisch O, Montóia VR \& Bauch J (2003) Dendroecological investigations on Swietenia macrophylla King and Cedrela odorata L. (Meliaceae) in the central Amazon. Trees 17: 244-250.

Gourlet-Fleury S \& Houllier F (2000) Modelling diameter increment in a lowland evergreen rain forest in French Guiana. Forest Ecology and Management 131: 269-289.

Graham EA, Mulkey SS, Kitajima K, Phillips NG \& Wright SJ (2003) Cloud cover limits net $\mathrm{CO}_{2}$ uptake and growth of a rainforest tree during tropical rainy seasons. Proceedings of the National Academy of Sciences 100: 572-576.

Grogan J \& Schulze M (2012) The impact of annual and seasonal rainfall patterns on growth and phenology of emergent tree species in Southeastern Amazonia, Brazil. Biotropica 44: 331-340.

Magalhães NDS, Marenco RA \& Camargo MAB (2014) Do soil fertilization and forest canopy foliage affect the growth and photosynthesis of Amazonian saplings? Scientia Agricola 71: 58-65. 
Malhi Y, Nobre AD, Grace J, Kruijt B, Pereira MGP, Culf A \& Scott S (1998) Carbon dioxide transfer over a Central Amazonian rain forest. Journal of Geophysical Research: Atmospheres 103: 3159331612.

Marenco RA, Nascimento HCS \& Magalhães NS (2014) Stomatal conductance in Amazonian tree saplings in response to variations in the physical environment. Photosynthetica 52: 493-500.

Marques JDO, Libardi PL, Teixeira WG \& Reis AM (2004) Study of physical, chemical and hydric parameter of a xanthic ferralsol in the Amazon region. Acta Amazonica 34: 145-154.

Martin CE, Rux G \& Herppich WB (2013) Responses of epidermal cell turgor pressure and photosynthetic activity of leaves of the atmospheric epiphyte Tillandsia usneoides (Bromeliaceae) after exposure to high humidity. Journal of Plant Physiology 170: 70-73.

McWilliam ALC, Roberts JM, Cabral OMR, Leitao MVBR, Costa ACL, Maitelli GT \& Zamparoni CAGP (1993) Leaf area index and above-ground biomass of terra firme rain forest and adjacent clearings in Amazonia. Functional Ecology 7: 310-317.

Mori SA (1989) Diversity of Lecythidaceae in the Guianas: Tropical forests: botanical dynamics, speciation \& diversity (ed. by LB Holm-Nielsen, IC Nielsen \& H Balslev) Academic Press, pp. 319-334.

Mulkey SS, Kitajima K \& Wright SJ (1996) Plant physiological ecology of tropical forest canopies. Tree 11: 408-412.

Oliveira AA \& Mori SA (1999) A central Amazonian terra firme forest. I. High tree species richness on poor soils. Biodiversity \& Conservation 8: 1219 1244.

Pelissier R \& Pascal J-P (2000) Two-year tree growth patterns investigated from monthly girth records using dendrometer bands in a wet evergreen forest in India. Journal of Tropical Ecology 16: 429446.

Rankin-de-Mérona JM, Prance GT, Hutchings RW, Silva MF, Rodrigues WA \& Uehling ME (1992) Preliminary results of a large-scale tree inventory of upland rain forest in the Central Amazon. Acta Amazonica 22: 493-534.

Ranzani G (1980) Identificação e caracterização de alguns solos da Estação Experimental de Silvicultura Tropical do INPA. Acta Amazonica 10: 7-41.

Restrepo-Coupe N, Rocha HR, Hutyra LR, Araújo AC, Borma LS, Christoffersen B, Cabral OMR, de Camargo PB, Cardoso FL, Lola da Costa AC,
Fitzjarrald DR, Goulden ML, Kruijt B, Maia JMF, Malhi YS, Manzi AO, Miller SD, Nobre AD, vin Randow C, Abreu Sa LD, Sakai RK, Tota J, Wofsy SC, Zanchi FB \&Saleska SR (2013) What drives the seasonality of photosynthesis across the Amazon basin? A cross-site analysis of eddy flux tower measurements from the Brasil flux network. Agricultural and Forest Meteorology 182: 128-144.

Rüdiger AL, Siani AC \& Veiga-Junior VF (2007) The chemistry and pharmacology of the South America genus Protium Burm. f. (Burseraceae). Pharmacognosy Reviews 1: 93-104.

Saatchi SS, Houghton RA, Dos Santos Alvala RC, Soares JV \& Yu Y (2007) Distribution of aboveground live biomass in the Amazon basin. Global Change Biology 13: 816-837.

Schippers P, Sterck F, Vlam M \& Zuidema PA (2015) Tree growth variation in the tropical forest: understanding effects of temperature, rainfall and $\mathrm{CO}_{2}$. Global Change Biology 21: 2749-2761.

Silva FAPRC, Robert RCG, Santos AS \& Mendonça SD (2015) Quantification and assessment of the main forest species licensed for exploitation in the state of acre from 2005 to 2012. Floresta e Ambiente 22: 567-574.

Stark SC, Enquist BJ, Saleska SR, Leitold V, Schietti J, Longo M, Alves LF, Camargo PB \& Oliveira RC (2015) Linking canopy leaf area and light environments with tree size distributions to explain Amazon forest demography. Ecology Letters 18: 636-645.

Vieira S, Camargo PB, Selhorst D, Silva R, Hutyra L, Chambers JQ, Brown IF, Higuchi N, Santos J, Wofsy SC, Trumbore SE \& Martinelli LA (2004) Forest structure and carbon dynamics in Amazonian tropical rain forests. Oecologia 140: 468479.

Wagner F, Rossi V, Aubry-Kientz M, Bonal D, Dalitz H, Gliniars R, Stahl C, Trabucco A \& Herault B (2014) Pan-tropical analysis of climate effects on seasonal tree growth. PloS One 9: e92337.

Wagner F, Rossi V, Stahl C, Bonal D \& Herault B (2012) Water availability is the main climate driver of neotropical tree growth. PloS One 7: e34074.

Worbes M (1999) Annual growth rings, rainfall-dependent growth and long-term growth patterns of tropical trees from the Caparo Forest Reserve in Venezuela. Journal of Ecology 87: 391-403.

Zweifel R, Item H \& Häsler R (2000) Stem radius changes and their relation to stored water in stems of young Norway spruce trees. Trees 15: 50-57. 